\title{
MIEGO TRŪKUMO IৃTAKA SLAUGYTOJŲ EMOCINEI IR FIZINEI BŪKLEI BEI DARBO ATLIKIMUI
}

\author{
Aurelija Alčauskienè $\dot{1}^{1,2,3}$, Deimantė Vytaite் $\dot{e}^{2,3}$, Viktorija Grigaliūnienè2 \\ ${ }^{1}$ Kauno kolegijos Medicinos fakulteto Slaugos katedra, \\ ${ }^{2}$ Lietuvos sveikatos moksly universiteto Slaugos fakulteto Slaugos ir rūpybos katedra, \\ ${ }^{3}$ Lietuvos sveikatos mokslu universiteto ligoninès Kauno kliniku Skubios pagalbos skyrius
}

Raktažodžiai: miegas, miego trūkumas, skubios pagalbos skyrius, bendrosios praktikos slaugytojas.

\section{Santrauka}

Tyrimo tikslas - atskleisti, kokią įtaką miego trūkumas daro slaugytojų emocinei ir fizinei būklei bei darbo atlikimui.

Atliktas kokybinis tyrimas. Tyrimo metodas - kokybinè turinio analizè. Tyrimo priemonè - pusiau struktūrinis interviu, kuris buvo atliekamas žodžiu, informacija įrašoma ị diktofoną ir vèliau transkribuojama. Tyrimas vyko 2019 m. gruodžio ir $2020 \mathrm{~m}$. sausio mènesiais. Tyrime dalyvavo 7 bendrosios praktikos slaugytojos, dirbančios skubios pagalbos skyriuje, dvidešimt keturių darbo valandų pamainomis.

Tyrimo rezultatai. Tyrime dalyvavusios bendrosios praktikos slaugytojos atskleidè savo nuomonę ir išgyvenimus, susijusius su miego trūkumu, atsiradusiu dirbant skubios pagalbos skyriuje dvidešimt keturių darbo valandų pamainomis. Vertinant tyrimo metu atskleistą miego trūkumo įtaką slaugytojų emocinei sveikatai, respondentès išreiškè, jog darosi sunku suvaldyti savo emocijas, atsiranda nepagrịstas liūdesys, nerimo jausmas, padidejja jautrumas, dirglumas, irzlumas, mažèja kantrybè, vengiama bendrauti su pacientais, jų artimaisiais bei kolegomis, o tai išprovokuoja dažnesnius konfliktus, prastejja komandinis darbas. Tyrimo rezultatai atskleide, jog miego trūkumas slaugytojams sukelia fizinį nuovargị, galvos, raumenų skausmus, atsiranda atminties, virškinamojo trakto, širdies ir kraujagyslių sistemos, menstruacinio ciklo sutrikimų, nemiga bei prasteja miego kokybè. Bendrosios praktikos slaugytojų nuomone, miego trūkumas trukdo tinkamai atlikti darbo funkcijas: sulèteja darbas, pasiruošimas procedūroms, atsiranda dèmesio sutrikimų, prarandamas pastabumas, atidumas, mažèja našumas, didèja klaidų tikimybè, slaugytojai dažniau susižeidžia manipuliacijų metu, prastejja darbo kokybė ir mažèja pasitenkinimas juo. Miego trūkumas sukelia daug neigiamų padarinių slaugytojų emocinei bei fizinei būklei, turi neigiamos ịtakos darbui, todèl svarbu pasirūpinti slaugytojų tinkama miego kokybe bei poilsio režimu.

\section{Ivadas}

Bendrosios praktikos slaugytojai yra labai svarbi sveikatos priežiūros sistemos grandis, jų darbas nenutrūkstamas, jie pamiršta save, teikdami pirmenybę pacientų poreikiams. Vis labiau didejjanti slaugytojų veiklos problema yra ilgų darbo valandų sukeltas miego trūkumas ir jo padariniai sveikatai. Miegas žmogui yra gyvybiškai svarbus procesas, reikalingas gerai psichinei bei fizinei sveikatai palaikyti [1].

Skubiosios pagalbos skyriuje dirbančiam personalui nepavyksta laikytis rekomenduojamo darbo ir poilsio režimo, nes dirbama ilgomis dvidešimt keturių darbo valandų pamainomis, todèl kenčia slaugytojų fizinė ir psichologinè sveikata. Neretai atsiranda ịvairių kognityvinių funkcijų sutrikimų, psichologinių problemų, sumažèja dèmesio koncentracija, darbo efektyvumas bei pasitenkinimas juo [2]. Tyrimais ịrodyta, jog miego trūkumas sukelia ịvairių neigiamų padarinių žmogaus sveikatai. Dar 2007 m. Tarptautinè véžio tyrimų agentūra (Prancūzija) pamaininị darbą, kuris sutrikdo ir išbalansuoja natūralų žmogaus miego ir cirkadinị ritmą, ịvardijo kaip galimą karcinogeną [3]. J. Ruggiero ir T. Avi-Itzhak atliktame tyrime su skubiosios pagalbos skyriuje dirbančiais slaugytojais buvo nustatya, jog po ilgų darbo valandų slaugytojai jausdavosi mieguisti, tačiau negreitai užmigdavo, o miego kokybė buvo prastesnè nei tų, kurie dirbo trumpiau [4]. Darbas pamainomis bei miego trūkumas gali suprastinti gyvenimo, o kartu ir miego kokybę, paveikti psichikos sveikatą ar sukelti depresiją [5]. Tyrimai atskleidè miego trūkumo sukeliamus elgsenos ir neurologinius pokyčius, kurių dažnai žmogus net nepastebi. Sutrikimų amplitude svyruoja nuo lengvų, tokių kaip dèmesio susilpnejjimas ir reakcijos laiko 
pailgèjimas iki sudètingesnių, tokių kaip klaidos, priimant svarbius sprendimus, ar atliekant medicinines procedūras [6]. Tyrimais įrodyta, jog gerai išsimiegojęs žmogus darbą atlieka greičiau nei tas, kuriam pasireiškęs miego trūkumas [7]. Miego trūkumas turi neigiamos įtakos atliekant darbus ir priimant svarbius sprendimus, dažniau daromos ir rečiau pastebimos kolegų klaidos, klystama dozuojant ar pasirenkant vaistus [8]. Esant miego trūkumui, slaugytojų darbas tampa labai sunkus, atsiranda stresas, galimas perdegimas, o kartu ir nerimas, bei dar didesné nemiga. Slaugytojai tampa jautrūs, pažeidžiami, blogėja jų nuotaika, mažèja noras bendrauti, prastejja komunikavimo ịgūdžiai ir gebejjimas valdyti emocijas [9,10]. 2012 metais A. Stimpfel, D. Sloane ir L. Aiken atliktame tyrime buvo nustatytas sumažèjęs pacientų pasitenkinimo lygis slaugytojais, kurių darbo pamainos trukmé buvo daugiau nei trylika valandų [11]. Mokslininkai teigia, jog slaugytojų darbas tapo labai varginantis, kupinas streso bei ịtampos, kurią didina įtempti santykiai kolektyve, pacientų reiklumas, labai dideli darbo krūviai bei ilgos darbo valandos, siejamos su miego trūkumu [9].

Tyrimo klausimai. 1. Kaip manote, kokią įtaką miego trūkumas turi slaugytojų fizinei ir emocinei sveikatai? 2. Su kokiais darbo sunkumais susiduria slaugytojai, kuriems pasireiškia miego trūkumas?

Tyrimo tikslas - atskleisti, kokią ịtaką miego trūkumas daro slaugytojų emocinei ir fizinei būklei bei darbo atlikimui.

\section{Tyrimo medžiaga ir metodai}

Bendrosios praktikos slaugytojų nuomonei ir patirtims atskleisti buvo pasirinktas kokybinio tyrimo metodas, taikant kokybinę turinio analizę, atliekant tiesioginius, pusiau struktūrinius interviu. Analizuojant interviu tekstus, buvo galima gilintis ị bendrosios praktikos slaugytojų patirtis, išgyvenimus, emocijas ir išsamiai jas atskleisti. Tyreja vyko $\mathfrak{i}$ Lietuvos universiteto ligoninés vaikų skubiosios pagalbos skyrių susitarti ir gauti sutikimą dèl būsimų interviu su ten dirbančiais bendrosios praktikos slaugytojais vietos ir laiko. Su kiekvienu tyrimo dalyviu buvo susitarta, kokioje vietoje ir kokiu laiku vyks tyrimas. Interviu metu informacija buvo ịrašoma ị diktofoną, vèliau transkribuojama, transkripcijos tekstai surenkami Microsoft Word 2013 programoje ir tyrejos suskirstyti. Transkribuojant interviu, dalyvių kalba neredaguota. Tyrimas buvo atliekamas $2019 \mathrm{~m}$. gruodžio ir $2020 \mathrm{~m}$. sausio ménesiais. Tyrime dalyvavo 7 bendrosios praktikos slaugytojos, dirbančios vaikų skubiosios pagalbos skyriuje. Prieš atliekant tyrimą, pasirinktas imties sudarymo būdas - patogioji tikslinè atranka. Atrankos kriterijai: dirba skubiosios pagalbos skyriuje; darbo laikas - budejimas dvidešimt keturias valandas; yra sutikimas dalyvauti tyrime. Tyrimo dalyvių darbo patirties vidurkis 9,7 metai skubiosios pagalbos skyriuje. Amžiaus vidurkis 32 metai. Trys tyrime dalyvavusios bendrosios praktikos slaugytojos turi aukštaji universitetinị išsilavinimą, keturios - aukštaji neuniversitetini. Visos tyrime dalyvavusios respondentės yra moterys. Pusiau struktūrinio interviu forma pagrịsta iš anksto nustatytais pagrindiniais klausimais, kuriuos sukūre tyrimo autorè. Jie neleidžia respondentui per daug nukrypti nuo analizuojamos temos, pasakojant savo patirtis, tačiau forma yra lanksti, nes tiriamajam teikia galimybę plèsti esamą temą, atskleidžiant savo išgyvenimus bei jausmus, nesant griežtų apribojimų ar pokalbio nutraukimo rizikos. Interviu metu buvo galima užduoti spontaniškų klausimų, siekiant geriau suprasti, ką tiriamasis nori pasakyti, ar padèti jam lengviau išsakyti savo jausmus. Pusiau struktūrinis interviu metodas nevaržo tyrèjo ir dalyvio, pagrindiniai klausimai numatomi iš karto, bet nenumatomi atsakymai, galima užduoti patikslinančių klausimų, nenukrypstant nuo pagrindinès temos ir klausimo esmès [12]. Interviu atsakymai buvo analizuojami ir skirstomi ị kategorijas, suformuotas išanalizavus mokslinę literatūrą. Gautieji duomenys buvo analizuojami bei interpretuojami ir pateikiamos ịžvalgos. Transkribuoti tekstai koduojami, naudojant reikšminius žodžius, kurie pagal prasmę jungiami ị kategorijas, iš kurių formuojamos temos, atitinkančios tyrimo klausimus.

\section{Tyrimo rezultatai}

Visos tyrime dalyvavusios bendrosios praktikos slaugytojos išsakè savo nuomonę bei savo patirti apie miego trūkumo itaką jų fizinei bei emocinei sveikatai ir darbo atlikimui.

Miego trūkumo ịtaka slaugytojų emocinei būklei. I klausimą, kokią įtaką emocinei būklei, slaugytojų nuomone, joms sukelia miego trūkumas, vienas dažniausių atsakymų buvo, jog padidejja dirglumas bei irzlumas: „Būnu be proto dirgli, kas nors ka nors ne taip pasako, viska labai asmeniškai priimu "(BPS1). Dažnai pasireiškia pyktis: „<...> draugai jau žino, kad geriau ta diena manęs nejudinti, būnu labai pikta "(BPS7). Slaugytojos pastebèjo, jog po ilgų darbo valandų, trūkstant miego, pasidaro liūdnos, atsiranda nerimo jausmas: „Labai dažnai grịžtu labai pavargusi ir dèl to būna labai liūdna "(BPS5). Kai pasireiškia miego trūkumas, slaugytojos dažnai skaudžiau ir jautriau reaguoja ị kritiką, dalykus priima asmeniškai ir tai veikia jų emocinę būklę: ,, Kai būnu pavargus, labiau reaguoju i negatyvius tévu pasakymus $<\ldots>$ tada atrodo, gali viska mesti ir išeiti, kai būnu pailsèjus taip nebūna, tada tiesiog juos nuraminu ir vèl viska paaiškinu "(BPS5). Pasireiškus miego trūkumui, padažnėja konfliktų su pacientais: „, Dirbant skubioj pagalboj, kai krūvis didelis, daug pacientu, tai net ir pusei dienos tik praejjus jauti, kad dažniau konfliktuoti su tévais pradedi "(BPS3). Slaugytojų nuomone, miego trūkumas išprovokuoja konfliktus ne tik su pacientais, bet ir su kolegomis, prastejja komandinis darbas: „Labai sunku 
bendradarbiauti su kolegomis, kai visi dirbame 24 valandas, nes visi pavargstame, žymiai daugiau konfliktuojame dienos pabaigoje, nei pradžioje "(BPS4). Pasireiškus miego trūkumui, slaugytojos dažniau nesuvaldo savo emocijų: ,,Kai pavargus esu, ì viska kitaip reaguoju, yra karta buvę, kad vaikas taip garsiai šaukè, tai aš jam atgal šaukti pradẻjau, tiesiog nesusivaldžiau "(BPS2). Miego trūkumas dažnai sukelia slaugytojų apatiškumą pacientų atžvilgiu: ,, Visi žinome, kad slaugytojo profesijoje labai svarbu yra noras padeti pacientui, ju poreikiu iškèlimas aukščiau nei savuju, bet, kai man trūksta miego, viskas būna atvirkščiai, kaip tik tampu apatiška"(BPS7).

Miego trūkumo ịtaka slaugytojų fizinei būklei. İ klausimą, kokią įtaką slaugytojų fizinei būklei sukelia miego trūkumas, visos tiriamosios atsakè, kad stipriausiai pasireiškiantis požymis yra fizinis nuovargis: „,Nuo to didžiulio nuovargio dar net darbe būdama dažniausiai pastebiu tiesiog tokị bendrą kūno silpnuma, negaliu išnaudot visu savo kūno galimybiu, atrodo, kad jis tiesiog išjungtas "(BPS5). Slaugytojos nurodè ir kitą svarbų požymį, sakydamos, jog grịžusios po darbo net ir pamiegojusios nesijaučia pailsejjusios, dažnai atsibunda dar prastesnès būklès, pasireiškia galvos skausmai: „Kai pamiegu, kai grižtu iš darbo, tai tada labai skauda ir svaigsta galva, prireikia net vaistu išgerti “(BPS2). Apklaustoms slaugytojoms dèl miego trūkumo atsiranda ne tik galvos, bet ir raumenų skausmai, bendras kūno silpnumas: ,,Man dažniausiai pasireiškia koju raumenu skausmas, kai grižtu namo, bet būna ịvairiai, priklauso nuo budèjimo sunkumo, gali ir budejjimo metu pradèti skaudeti “(BPS3). Neretai grižusioms namo po budèjimo slaugytojoms pasireiškia nemiga, nes vakare ịprastu laiku nebegali užmigti: , Kai grịžus iš darbo miegu dienomis, tai vakare man būna sunku vèl užmigti, tai labai dažnai man pasireiškia nemiga "(BPS4). Nuo ilgų darbo valandų, didelio miego trūkumo, nereguliaraus valgymo apklaustoms slaugytojoms sutrinka virškinimo sistema: „Būna tokiu dienu, kad net pykinima jaučiu, dèl to didžiulio nuovargio ir didelio miego trūkumo "(BPS6). Kitas fizinis simptomas, pasireiškiantis apklaustoms slaugytojoms, patiriančioms miego trūkumą, yra sutrikęs menstruacijų ciklas: ,Ka dar pastebejjau, kai pradejau dirbti skubioj pagalboj ir būtent tokiu darbo grafiku, kad mènesinès tapo labai nereguliarios "(BPS1). Miego trūkumas turi ịtakos slaugytojų širdies ir kraujagyslių sistemai: „Ko anksčiau nebüdavo, kol nedirbau skubioj pagalboj ir dar paromis, tai problemu su širdimi, o dabar tai kartais tokị keista skausma patiriu širdies plote: dusulys pasireiškia "(BPS7). Taip pat dèl miego trūkumo slaugytojos pažymèjo, jog joms pradeda drebèti rankos: „I darbo pabaiga, kai būnu jau labai išsekusi, tai jaučiu, kad net rankos drebèti pradeda"(BPS1).

Miego trūkumo sukelti darbo sunkumai. Antruoju tyrimo klausimu buvo siekiama atskleisti, kokius darbo sunkumus patiria pavargę bendrosios praktikos slaugytojai. Pirmiausia buvo kalbama apie tai, kad miego trūkumas sunkina darbą su pacientais, su jais sunkiau susikalbèti, mokyti ar padèti: „,Net pati pajaučiu, kad i pacientu klausimus būna sudètinga atsakinèti, norisi greitai ir trumpai atsakyti ir nieko daugiau neaiškinti “(BPS3). Interviu metu slaugytojos pabrèžè, kad pasireiškus miego trūkumui, sulètèja darbo atlikimas: „Nepalyginsi, kaip dienos metu būna paprasta ivvesti kateterị ar sušvirkšti vaistus, o kur nakti viska reikia padaryti, atrodo, kad dvigubai lèčiau viska darai "(BPS4). Slaugytojos pastebejo, kad suletėja ne tik fiziniai judesiai, bet ir mąstymas: „Kai jaučiu miego trūkuma, tai pastebiu, kad net mąstymas suletejja, dienos metu atrodo viska automatiškai žinai, o naktị net elementarūs dalykai atrodo labai sudetingi "(BPS4). Esant miego trūkumui, sumažèja pasitikèjimas savimi, tad slaugytojos dažniau tikrina vaistų dozes, paskyrimus, ar tinkamą vaistą pasiemè ir kita: ,Ǎ̌ pastebiu, kad, kai esu pavargusi, viska labiau tikrinu, kad tik nepadaryčiau tos klaidos "(BPS3). Slaugytojos pastebejo, jog jausdamos miego trūkumą, ilgiau ruošiasi manipuliacijoms: ,,Tikrai esu pastebejjusi, kad kai jaučiu miego trūkuma, ilgiau ruošiuosi padèkliuka, nors procedūra jau iki gyvo kaulo žinau, bet turiu ilgiau pagalvoti, pavyzdžiui, kiek pleistriuku man reikia"(BPS7). Slaugytojos nurodè, jog pavargusios praranda pastabumą: ,, Naktị dažnai ilgiau ieškau, kur padètos darbo priemonès, nepastebiu, kas prieš akis padèta "(BPS3). Tyrimo dalyvès nurodè, jog dèl miego trūkumo jų darbas tampa mažiau efektyvus, jos tampa mažiau produktyvios: ,Dienos pradžioje daug greičiau ir produktyviau viska padarau, negu naktį, kai jau trūksta to miego "(BPS1). Miego trūkumas kelioms tyrimo dalyvėms sukèlè atminties sutrikimą: ,, Atrodo, nebeprisimenu dalyku, kai paklausia, kokia vaiko temperatūra, ka tik matavau, o jau neprisimenu, kokia ji buvo "(BPS2). Slaugytojų nuomone, miego trūkumas joms sukelia dèmesio sutrikimus, tokius kaip koncentracijos nebuvimas, reakcijos greičio pailgejjimas: „Labai suprasteja dèmesio koncentracija, reakcijos greitis pailgeja, yra ne viena karta buvę, kad vedu kateteri ir kraujas pradeda bègti pro ta kaniulę, tai kol kamšteli uždedu, prikraujuoja visur, tokia kaip ne su savom rankom pradedu dirbti "(BPS6). Dèl miego trūkumo didèja klaidų atsiradimo rizika: „Dažniau klaidu pati padarau naktimis, kai smegenys pavargusios, o kūnas nori miegoti, o tau reikia dirbti “(BPS7). Slaugytojoms, kurioms pasireiškia miego trūkumas, didèja rizika susižeisti, atliekant manipuliacijas. Dalyvès iš savo patirties nurodè: ,Labai daug karty yra buvę, kad suleidi vaistus, uždarineji adata ir isiduri, akyse liejasi, nematai normaliai kur tas kamštelis "(BPS4). Dèl miego trūkumo prastejja slaugytojų darbo kokybė: „Pastebéjau, kad kai atlieku kažkokias tai manipuliacijas, dažniausiai naktị, kai jau tikrai būna miego poreikis didžiulis, tai viska 
darau lèčiau ir ta kokybè būna prastesnè, dažniau ì vena nepataikau"(BPS5). Interviu dalyvavusioms slaugytojoms dèl miego trūkumo mažèja pasitenkinimas darbu: , Tikrai jautiesi nepasitenkinęs darbu, kai jau vakare ta tavo darbo kokybè yra prasta, jautiesi pavargęs, nepailsejjęs, pradedi save nuvertinti, abejoti savo gabumais ir tau nesiseka, bet dèl to kaltas būna nuovargis "(BPS2).

Slaugytojų požiūris ị ilgas darbo valandas. Paklausus slaugytojų, kodèl jos pasirinko dirbti tokias ilgas darbo valandas, dažniausias atsakymas buvo, jog dèl finansinès padèties: „Ǎ̌ manau, kad dirbti 24 valandu pamainomis pasirenkama dèl finansinès padèties, žmonès nori daugiau užsidirbti, nes atlyginimai pas mus tikrai maži “(BPS2). Klausėme slaugytojų, ar, esant galimybei, jos rinktųsi trumpesnes darbo valandų pamainas ir sulaukème bendro teigiamo atsakymo: ,,Jeigu būtu galimybè, tikrai rinkčiausi dirbti bent dvylikos valandu pamaina, nes tas dvidešimt keturias valandas tikrai sunku išbüti “(BPS2). ,Jeigu man pasiūlytu dirbti dvylikos valandu pamaina ir gera atlyginima, mielai sutikčiau, nes parq išdirbti yra tikrai labai sunku“"(BPS3).

\section{Diskusija}

Vertinant tyrimo metu atskleistą miego trūkumo įtaką slaugytojų fizinei sveikatai, visos tyrimo dalyvès sakè, jog ryškiausias požymis yra fizinis nuovargis. Šiuos rezultatus patvirtino ir literatūros šaltinių analizè. 2019 metais S. Ose su kolegomis atliktas tyrimas parodé, jog pasireiškus miego trūkumui, vienas svarbiausių padarinių yra slaugytojų patiriamas didelis nuovargis [13]. Mūsų tyrimo rezultatai atskleidè, jog slaugytojoms miego trūkumas gali sukelti galvos, raumenų, nugaros skausmus. Tai ịrodoma ir kituose analizuotuose šaltiniuose. Kinijoje atliktame tyrime buvo nustatyta, jog galvos skausmas yra vienas ryškiausių miego trūkumo padarinių [14].

Tyrimo rezultatai parodè, jog slaugytojoms dèl miego trūkumo padidèja jautrumas, atsiranda irzlumas, dirglumas. Tai ịrodo ir analizuota literatūra. C. Huang su bendraautoriais aprašè tyrimą, kuris ịrodè, jog dèl miego trūkumo slaugytojams padidèja nerimo lygis, atsiranda didesnis jautrumas, stresas [9]. Atliktas tyrimas atskleide, jog slaugytojos skundžiasi prastesne psichine sveikata. Dažniau patiria nerimą, nepagrịstą liūdesị. Tokius rezultatus patvirtina ir analizuota literatūra. E. Nena ir kt. atliktame tyrime buvo nustatyta, jog dauguma (58.2 proc.) tyrime dalyvavusių pamainomis dirbančių slaugytojų yra visiškai nepatenkinti savo miego kokybe, skundžiasi prasta psichine sveikata [15]. Tyrimo rezultatai atskleidè, jog slaugytojoms dèl miego trūkumo mažèja pasitenkinimas darbu. P. Ioannou ir kt. atliktame tyrime buvo ịrodyta, jog dèl sunkių darbo sąlygų, tokių kaip ilgos darbo valandos, slaugytojai jaučiasi pavargę, mažèja pasitenkinimas darbu, prasteja sveikata, o kartu ir gyvenimo kokybė [16].
Tyrimas atskleidè, jog dèl miego trūkumo prastèja atliekamo darbo kokybè. Tai ịrodo ir nagrinèti moksliniai darbai. A. Stimpfel ir kt. atliktame tyrime buvo įrodyta, jog trumpiau miegoję slaugytojai mažiau domėjosi ir rūpinosi pacientais, statistiškai reikšmingai prasčiau atliko darbus, todèl prastèjo slaugos kokybė. Remdamiesi tyrimo rezultatais, autoriai iškèlè svarbią problemą, nurodę, jog slaugytojų miego trūkumas kenkia ir pacientams, nes prasteja slaugymo kokybė [17]. Tyrimo rezultatai atskleidè, jog esant miego trūkumui, didèja padaromų klaidų skaičius bei jų atsiradimo rizika. Tokius rezultatus patvirtina ir nagrinèti literatūros šaltiniai. M. Shao ir kt. atliktame tyrime, kuriame dalyvavo 435 bendrosios praktikos slaugytojai, buvo nustatyta, jog miego trūkumas didina slaugytojo klaidų riziką [18]. Apibendrinant galime teigti, jog miego trūkumas sukelia daug neigiamų padarinių slaugytojų emocinei bei fizinei būklei, turi neigiamos ịtakos atliekamam darbui, todèl svarbu rūpintis tinkama slaugytojų miego kokybe, laikytis poilsio režimo.

\section{Išvados}

1. Tyrime dalyvavusios bendrosios praktikos slaugytojos atskleidè savo nuomonę ir išgyvenimus, susijusius su miego trūkumu, dirbant skubiosios pagalbos skyriuje dvidešimt keturių valandų pamainomis. Respondentų teigimu, miego trūkumas slaugytojams sukelia fizini nuovargi, išprovokuoja galvos, raumenų skausmus, tachikardiją, atsiranda rankų drebulys, atminties, virškinamojo trakto, širdies ir kraujagysliu sistemos, menstruacinio ciklo sutrikimų, prasideda nemiga, prastejja miego kokybè. Sunku valdyti emocijas, atsiranda liūdesys, nerimo jausmas, padidejja jautrumas, dirglumas, irzlumas, mažeja kantrybė. Slaugytojos vengia bendrauti su pacientais, kolegomis, o tai išprovokuoja konfliktus, apatiškumą pacientų atžvilgiu.

2. Tyrimo eigoje atskleista, jog pasireiškęs miego trūkumas trukdo tinkamai atlikti darbo funkcijas. Bendrosios praktikos slaugytojų nuomone, dèl to prasteja komandinis darbas, lètėja darbo sparta, pasiruošimas procedūroms, atsiranda dèmesio sutrikimų, prarandamas pastabumas, atidumas, mažeja darbo našumas, dideja klaidų rizika, slaugytojai dažniau susižeidžia manipuliacijų metu, prastejja atliekamo darbo kokybė bei mažèja pasitenkinimas juo.

\section{Literatūra}

1. Hirshkowitz M, Whiton K, Albert SM, Alessi C, Bruni O, DonCarlos L, et al. National Sleep Foundation's sleep time duration recommendations: methodology and results summary. Sleep Health 2015;1(1):40-43.

https://doi.org/10.1016/j.sleh.2014.12.010

2. Januškevičienė L. Nuolatinis kokybiško miego trūkumas gali kainuoti net gyvybę. Spectrum 2019;30:42-43.

3. International agency for research on cancer group 2A: probably 
carcinogenic to humans. https://www.cancer.org/cancer/cancercauses/general-info/known-and-probable-human-carcinogens. html

4. Ruggiero JS, Avi-Itzhak T. Sleep patterns of emergency department nurses on workdays and days off. J Nurs Res 2016;24(2):173-180.

https://doi.org/10.1097/jnr.0000000000000121

5. Skipper JK, Jung FD, Coffey LC. Nurses and shiftwork: effects on physical health and mental depression. J Adv Nurs 1990;15(7):835-842. https://doi.org/10.1111/j.1365-2648.1990.tb01915.x

6. Landrigan CP, Rothschild JM, Cronin JW, Kaushal R, Burdick E, Katz JT, et al. Effect of reducing interns' work hours on serious medical errors in intensive care units. NEJM 2004;351(18):1838-1848.

https://doi.org/10.1056/NEJMoa041406

7. Goel N, Rao H, Durmer JS, et al. Neurocognitive consequences of sleep deprivation. Semin Neurol 2009;29(4):320-339. https://doi.org/10.1055/s-0029-1237117

8. Arzalier-Daret S, Buléon C, Bocca ML, Denise P, Gérard JL, Hanouz JL. Effect of sleep deprivation after a night shift duty on simulated crisis management by residents in anaesthesia. Randomized Controlled Trial. Anaesth Crit Care Pain Med 2018;37(2):161-166 https://doi.org/10.1016/j.accpm.2017.05.010

9. Huang CLC, Wu MP, Ho CH, Wang JJ. Risks of treated anxiety, depression, and insomnia among nurses: a nationwide longitudinal cohort study. PloS One 2018;13(9):e0204224. https://doi.org/10.1371/journal.pone.0204224

10. Caruso CC. Negative impacts of shiftwork and long work hours. Rehabil Nurs 2014;39(1):16-25. https://doi.org/10.1002/rnj.107

11. Stimpfel AW, Sloane DM, Aiken LH. The longer the shifts for hospital nurses, the higher the levels of burnout and patient dissatisfaction. Health Aff (Millwood) 2012;31(11):2501-9. https://doi.org/10.1377/hlthaff.2011.1377

12. Elo S, Kääriäinen M, Kanste O, Pölkki T, Utriainen K, Kyngäs H. Qualitative content analysis: a focus on trustworthiness. SAGE Open 2014;4(1):1-10. https://doi.org/10.1177/2158244014522633

13. Ose SO, Tjønnås MS, Kaspersen SL, Færevik H. One-year trial of 12-hour shifts in a non-intensive care unit and an intensive care unit in a public hospital: a qualitative study of 24 nurses' experiences. BMJ Open 2019;9(7):e024292.

https://doi.org/10.1136/bmjopen-2018-024292

14. Liu H, Liu J, Chen M, et al. Sleep problems of healthcare workers in tertiary hospital and influencing factors identified through a multilevel analysis: a cross-sectional study in China. BMJ Open 2019;29:9(12):e032239.

https://doi.org/10.1136/bmjopen-2019-032239

15. Nena E, Katsaouni M, Steiropoulos P, et al. Effect of shift work on sleep, health, and quality of life of health-care workers.
Indian J Occup Environ Med 2018;22(1):29-34

https://doi.org/10.4103/ijoem.IJOEM_4_18

16. Ioannou $P$, Katsikavali V, Galanis $P$, et al. Impact of job satisfaction on greek nurses' health-related quality of life. PMC4682027, Saf Health Work 2015;6(4):324-328. https://doi.org/10.1016/j.shaw.2015.07.010

17. Perry L, Lamont S, Brunero S, Gallagher R, Duffield C. The mental health of nurses in acute teaching hospital settings: a cross-sectional survey. BMC Nurs 2015;14:15.

https://doi.org/10.1186/s12912-015-0068-8

18. Shao MF, Chou YC, Yeh MY, TzengWC. Sleep quality and quality of life in female shift working nurses. J Adv Nurs 2010; 66 (7):1565-1572.

https://doi.org/10.1111/j.1365-2648.2010.05300.x

\section{THE IMPACT OF SLEEP DEPRIVATION ON NURSES` EMOTIONAL, PHYSICAL HEALTH AND PRACTICAL SKILLS}

A. Alčauskienė, D. Vytaitė, V. Grigaliūnienè

Keywords: sleep, sleep deprivation, Emergency Department, nurse.

Summary

The aim of the study - to reveal the impact of sleep deprivation on nurses' emotional, physical health and practical skills. Methodology. A Qualitative study. Method - qualitative content analysis. Research instrument - semi-structured interview. It was performed orally, all of the information was recorded and later on transcribed. The research was carried out on 2019, December and 2020, January. The interview was carried out with 7 nurses working 24 hour shifts in the Emergency Department.

Research results. Nurses who participated in the research revealed their experiences and point of view due to sleep deprivation while working 24 hour shifts in the Emergency Department. According to the nurses who participated in the research, due to sleep deprivation it becomes difficult to manage their emotions, sadness, anxiety, increase of sensitivity, irritability, shortness of temper and patience diminishing appears. Nurses avoid to communicate with their patients and colleagues what causes more conflicts and apathy towards patients. Nurses pointed out that sleep deprivation causes physical fatigue, headaches, muscle pain, tachycardia, memory loss, digestive tract, cardiovascular system and menstrual cycle disorders, insomnia, decreased sleep quality. Nurses revealed that sleep deprivation has a major impact on their work functions. It deteriorates team work, slows down work performance and it takes longer to get ready for procedures. Attention disorders and lack of alertness occur. Sleep deprivation causes major decrease in productivity it also can increase the number of errors. Nurses tend to get more injuries while performing procedures and manipulations. It has a tendency to decrease work quality and job satisfaction.

In conclusion, sleep deprivation has a major negative impact on nurses ' emotional, physical health and practical skills. Therefore, it is very important to ensure nurses ' adequate quality of sleep and to provide opportunities to rest.

Correspondence to: deimantevyt97@gmail.com

Gauta 2020-09-11 